\title{
REVIEW ARTICLE OPEN \\ Crevice corrosion of nickel-based alloys considered as engineering barriers of geological repositories
}

\author{
Ricardo M. Carranza ${ }^{1}$ and Martín A. Rodríguez $\mathbb{D}^{1,2}$
}

Nickel-based alloys are considered among other candidate materials as engineering barriers of geological repositories due to their excellent corrosion resistance. These alloys possess unique advantages: they may be used in saturated and unsaturated repositories, hosted by practically any rock type, while also compatible with any (or no) backfill, and have minimal impact in other barriers. Alloy-22 (UNS N06022) has been the most studied of this class of alloys for its potential application in the proposed repositories (namely Yucca Mountain, USA). Crevice corrosion is however an important and often unintended degradation process that may limit the waste container lifetime if a nickel-based alloy is selected. Alloy susceptibility to crevice corrosion is influenced by environmental and metallurgical variables. This review gives an account of the current knowledge regarding crevice corrosion of nickel-based alloys as candidate materials for the corrosion-resistant layer of high-level nuclear waste containers. Although there is a significant amount of research supporting the use of nickel-based alloys for this application, the effect of the different variables on crevice corrosion resistance is described. Special focus is given to the current criterion for crevice corrosion occurrence in repository environments, recent works and criticisms. The presently established criterion appears robust for ruling out crevice corrosion in saturated repositories; however, the development of a less conservative criterion for crevice corrosion occurrence is necessary to use these alloys in unsaturated repositories.

npj Materials Degradation (2017)1:9; doi:10.1038/s41529-017-0010-5

\section{INTRODUCTION}

High-level nuclear waste (HLNW) is mainly produced from nuclear power generation, but also may arise from research facilities, disused sealed sources and defence programmes. HLNW contains large quantities of long-lived radionuclides and releases significant heat. Containment and isolation of HLNW from the environment is required to ensure long-term safety. ${ }^{1}$ There is a global consensus about the final disposal of HLNW in deep geological repositories. Repositories are multi-barrier systems made of engineered and natural barriers. ${ }^{2,3}$

Geological formations considered to host nuclear repositories include sedimentary clay deposits (France, Switzerland and Belgium), granitic rocks (Canada, Finland and Sweden), salt domes (Germany) and tuff rock (USA). ${ }^{3,4}$ Groundwater is the only considered carrier of radionuclides away from the repository. Selected host rock defines the groundwater system. The engineered barrier system (EBS) is designed taking into account the features of the natural system. The EBS includes the waste form, the waste container and the backfill material. ${ }^{2-4}$

The conditioned nuclear waste (waste form) is placed within a waste container (also called waste package or canister). The waste container must include a corrosion-resistant layer. The container is the only absolute barrier of the multi-barrier system: radionuclides will be released to the geosphere, only if the container fails. Container failure will eventually result from corrosion of its walls. In this context, appropriate selection of the material for the corrosion-resistant layer of containers is of paramount importance. Containment periods from 500 to $10^{6}$ years are required depending on the selected container material and host rock.
Different backfill materials have been proposed for filling and sealing the repository tunnels. The selected backfill material will influence the chemistry of the solution in contact with the waste containers. $^{5-8}$

Geological repositories may be categorised into two types from the viewpoint of containers corrosion: ${ }^{8}$

- Saturated repositories: containers are placed below the water table and surrounded by a backfill of compacted bentonite, cementitious material, crushed salt or no backfill. Oxygen is consumed in the short initial stage and then conditions become reducing. $^{3}$

- Unsaturated repositories: containers are placed above the water table and tunnels are not backfilled. Environmental conditions are always oxidising. The proposed Yucca Mountain repository (USA) is the only studied repository of this type. $^{4}$

Different materials have been proposed for the corrosionresistant layer of waste containers. Corrosion-allowance materials such as carbon steel and copper are suitable for saturated repositories. These materials corrode uniformly at a predictable rate in the anticipated repository environments. ${ }^{9}$ Copper is a corrosion-allowance material in the presence of oxygen but it is considered immune to corrosion in the absence of oxidising species other than $\mathrm{H}_{2} \mathrm{O} / \mathrm{H}^{+}$. However, copper thermodynamical immunity has been challenged. ${ }^{10}$ Corrosion-resistant materials such as stainless steels, nickel-based alloys and titanium alloys may be used in the two types of repositories. ${ }^{8,9}$ The degradation processes that limit the containers lifetime include general

\footnotetext{
${ }^{1}$ Gerencia Materiales, Comisión Nacional de Energía Atómica Instituto Sabato, UNSAM / CNEA, Av. Gral. Paz 1499, Buenos Aires B1650KNA, Argentina and ${ }^{2}$ Consejo Nacional de Investigaciones Científicas y Técnicas, Buenos Aires, Argentina

Correspondence: Ricardo M. Carranza (carranza@cnea.gov.ar) or Martín A. Rodríguez (maalrodr@cnea.gov.ar)
}

Received: 30 January 2017 Revised: 2 May 2017 Accepted: 3 July 2017

Published online: 16 October 2017 
corrosion, localised corrosion, stress corrosion cracking (SCC), hydrogen-assisted cracking and microbiologically influenced corrosion. $^{8}, 9,11$ Nickel-based alloys have very low general corrosion rates in the disposal environment due to the spontaneous development of a passive surface film. However, they are susceptible to localised corrosion such as pitting and crevice corrosion. Crevice corrosion is more likely to occur than pitting corrosion as it may stabilise in less harsh environmental conditions (lower potentials, temperatures and chloride concentration). ${ }^{12}$

The objective of this review paper is to give an account of the current knowledge with regard to crevice corrosion of nickelbased alloys as candidate materials for HLNW containers. The majority of this review will be devoted to alloy 22 (UNS N06022) to give way to the amount of literature dedicated to it, mainly during the Yucca Mountain Project (YMP). ${ }^{4}$ The information about tests in nickel-based alloys for other repositories has been extracted from the extensive report prepared for the 5th Euratom Framework Programme 1998-2002 and references therein. ${ }^{6}$

\section{Nickel-based alloys}

Nickel-based alloys are generally solid solutions of nickel and other elements. Large amounts of alloying elements can be added to nickel to produce a huge variety of alloys. Nickel-based alloys may be specially tailored for almost any specific application. They are generally classified into: ${ }^{13-15}$

- Corrosion-resistant alloys (CRAs), which were designed to resist low-temperature aqueous corrosion.

- High-temperature alloys (HTAs), which were designed to resist high temperature and dry or gaseous corrosion.

Nickel-based CRAs and HTAs are used in applications where the less expensive iron-based stainless steels do not perform well. Owing to their high nickel content, CRAs are highly resistant to SCC in hot chloride solutions, where austenitic stainless steels fail. In hot acids, CRAs also outperform stainless steels as nickel dissolves larger amounts of beneficial alloying elements (Mo, W, $\mathrm{Cu}$, etc.) than iron. ${ }^{13-15}$

Nickel-based CRAs can in turn be classified into (1) commercially pure $\mathrm{Ni},(2) \mathrm{Ni}-\mathrm{Cu}$ alloys, (3) Ni-Mo alloys, (4) Ni-Cr-Mo alloys and (5) $\mathrm{Ni}-\mathrm{Cr}-\mathrm{Fe}$ alloys. $\mathrm{Ni}-\mathrm{Cr}-\mathrm{Mo}$ and $\mathrm{Ni}-\mathrm{Cr}-\mathrm{Fe}$ alloys (with $\mathrm{Mo}$ additions) have been considered for the corrosion-resistant layer of HLNW containers. Addition of molybdenum and chromium provide corrosion resistance in reducing and oxidising hot acids, respectively. Chromium produces the formation of a thin protective passive film under oxidising conditions. Molybdenum, and in a lesser extent tungsten and copper, reduce the corrosion rate in conditions where the alloys are not covered with the passive film. $\mathrm{Ni}-\mathrm{Cr}-\mathrm{Fe}$ alloys (with Mo additions) are more corrosion-resistant than austenitic stainless steels of the 300 series but less resistant than $\mathrm{Ni}-\mathrm{Cr}-\mathrm{Mo}$ alloys. Table 1 lists the approximate composition and UNS number of some of the most popular nickel-based CRAs. ${ }^{15}$

YMP and several European nuclear waste management programmes have considered nickel-based alloys for the corrosion-resistant layer of waste containers. ${ }^{4,6}$ YMP considered alloys 825 (UNS N08825) and 625, and finally selected alloy $22 .^{5}$ European programmes considered alloys 625, 825, C-276 (UNS N10276) and C-4 (UNS N06455). ${ }^{6}$ Other studied nickel-based CRAs include the recently developed alloys C-22HS (UNS N07022), HYBRID-BC1 (UNS N10362), 59 (UNS N06059), C-2000 (UNS N06200), etc. ${ }^{16-19}$

Selection of a nickel-based alloy as the material for the corrosion-resistant layer of waste containers for saturated and unsaturated repositories has distinct advantages relative to other metals/alloys: ${ }^{20,21}$
Table 1. Chemical composition and PRE of selected nickel-based alloys

\begin{tabular}{lcll}
\hline Alloy & UNS & Chemical composition (wt.\%) & PRE \\
\hline 825 & N08825 & 43Ni-21Cr-30Fe-3Mo-2.2Cu-1Ti & 31 \\
C-276 & N10276 & 59Ni-16Cr-16Mo-4W-5Fe & 75 \\
625 & N06625 & $62 \mathrm{Ni}-21 \mathrm{Cr}-9 \mathrm{Mo}-3.7 \mathrm{Nb}$ & 51 \\
C-22 or 22 & N06022 & $59 \mathrm{Ni}-22 \mathrm{Cr}-13 \mathrm{Mo}-3 \mathrm{~W}-3 \mathrm{Fe}$ & 70 \\
C-4 & N06455 & $65 \mathrm{Ni}-16 \mathrm{Cr}-16 \mathrm{Mo}-3 \mathrm{Fe}-2 \mathrm{Co}-1 \mathrm{Mn}$ & 69 \\
C-2000 & N06200 & $59 \mathrm{Ni}-23 \mathrm{Cr}-16 \mathrm{Mo}-1.6 \mathrm{Cu}$ & 76 \\
59 & $\mathrm{~N} 06059$ & $59 \mathrm{Ni}-23 \mathrm{Cr}-16 \mathrm{Mo}-1 \mathrm{Fe}$ & 76 \\
686 & $\mathrm{~N} 06686$ & $46 \mathrm{Ni}-21 \mathrm{Cr}-16 \mathrm{Mo}-4 \mathrm{~W}-5 \mathrm{Fe}$ & 80 \\
C-22HS & $\mathrm{N} 07022$ & $59 \mathrm{Ni}-21 \mathrm{Cr}-17 \mathrm{Mo}$ & 77 \\
HYBRID-BC1 & $\mathrm{N} 10362$ & $62 \mathrm{Ni}-22 \mathrm{Mo}-15 \mathrm{Cr}-2 \mathrm{Fe}-0.3 \mathrm{Al}$ & 88 \\
\hline
\end{tabular}

- The expected containment is very long, synonymous with low corrosion rates.

- Thin-wall containers simplify joining and inspection (internal support required).

- Corrosion resistance can be tailored to specific environment by alloy selection.

- There is a minimal impact on other barriers.

- Good performance with bentonite backfill, cementitious backfill or with no backfill, in practically any host rock.

The main disadvantage (although not isolated to specifically to nickel-based alloys) is the need to predict long-term behaviour of a passive alloy, and that the corresponding international experience is based principally on a single national programme (YMP), ${ }^{4}$ with research confined to a relatively short period of time.

\section{CREVICE CORROSION OF NICKEL-BASED ALLOYS}

Crevice corrosion is a particular type of localised corrosion occurring on surfaces of metallic materials that are occluded from the bulk solution. Nickel-based alloys are prone to chlorideinduced crevice corrosion, and this type of attack is essentially the same as pitting corrosion from an electrochemical viewpoint. ${ }^{22}$ The difference between chloride-induced pitting and crevice corrosion is only geometrical. Both phenomena occur as a result of a local acidification process brought about by hydrolysis of the dissolved metal cations followed by anions migration into the cavity. ${ }^{12}$ Localised corrosion stabilises when the product of the diffusion path $(x)$ and the anodic current density of the metal in the local solution (i) increases above a critical value (CRIT), as stated in Eq. $1 .^{23}$ This criteria based on the stability product $(x \cdot i)$ is, of course, valid for both pitting and crevice corrosion. As the diffusion path of a crevice is much larger than that of a pit, crevice corrosion stabilises at a lower anodic current density than pitting corrosion, which in turns means stabilisation at a lower potential. Crevice corrosion will stabilise at a significantly lower potential than pitting corrosion depending on the anodic Tafel slope of the alloy in the local acidified solution, or more generally, depending on its anodic current density vs. potential relationship. ${ }^{12}$

$x \cdot i>(x \cdot i)_{\text {CRIT }}$

Alloy-22 is immune to pitting corrosion in the anticipated Yucca Mountain repository environment, ${ }^{5}$ whereas, for instance, alloy 825 (a former candidate material of YMP) is prone to pitting corrosion in similar conditions. ${ }^{24,25}$ Pitting corrosion immunity of alloy 22 results from a limitation of its anodic current density in the locally acidified solution to $20 \mathrm{~mA} / \mathrm{cm}^{2}$, as shown is Fig. $1 .{ }^{26}$ Such a low current density is insufficient to stabilise pitting corrosion at any potential. On the contrary, anodic current density of alloy 825 in simulated crevice/pit solution reaches much higher 


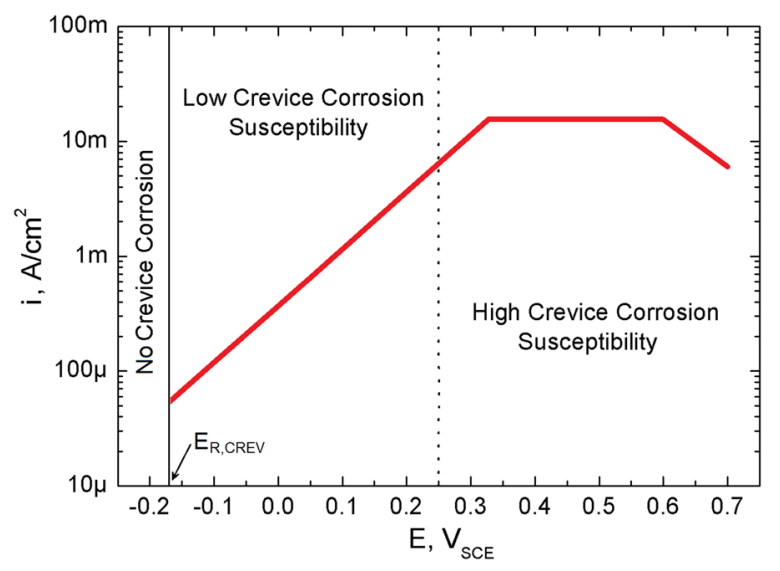

Fig. 1 Crevice corrosion current density as a function of the applied potential for alloy 22 in $\mathrm{pH} 2,1 \mathrm{~mol} / \mathrm{L} \mathrm{NaCl}$, at $90^{\circ} \mathrm{C}$. Reproduced with permission from ref. 26, NACE International, Houston, TX. All rights reserved. $\odot$ NACE International 2010

values allowing pitting corrosion stabilisation (Fig. 2). ${ }^{24}$ Pitting corrosion of alloy 22 only occurs in very concentrated chloride brines at near boiling temperatures. ${ }^{27}$

One of the main concerns for the performance of alloy 22 in the Yucca Mountain repository has been its resistance to crevice corrosion. ${ }^{5,28}$ Required lifetime for the container is 10,000 years. Consequently, a significant amount of research was devoted to this topic which resulted in an overall improvement of our knowledge of crevice corrosion. ${ }^{4,5}, 28-30$ Factors (variables) affecting the crevice corrosion resistance or susceptibility of nickel-based alloys in anticipated repository environments have been studied in some detail. ${ }^{31}$ They are classified into:

- Environmental (external) variables which are determined by the features of the modified environment surrounding the container. The modified environment includes the groundwater system, natural barriers, selected backfill and other engineering barriers. Typical variables: chloride concentration $\left(\left[\mathrm{Cl}^{-}\right]\right)$, temperature $(\mathrm{T})$, potential $(\mathrm{E})$, concentration of inhibitors ([lnh]), oxygen concentration $\left(\left[\mathrm{O}_{2}\right]\right)$, proton activity $(\mathrm{pH})$, microbial activity, volume of electrolyte (bulk solutions vs. thin films), crevice former geometry (tightness of the crevice), type of crevicing material, debris or deposits, radiation field, etc.

- Metallurgical (internal) variables which are determined by the chemical composition, microstructure, processing and finishing of the material. Container fabrication processes, storage conditions and transportation to repository site affect these variables. Typical variables: type of mill-annealing process (bright or black annealing), presence of a weld seam containing a cast or dendritic microstructure and a heat-affected zone (HAZ), post-welding treatments, metal finishing (roughness and defects), thermal-aging treatments (temperature and time of exposure), high-temperature or air-formed oxides, etc.

The localised corrosion resistance of nickel-based alloys is generally ranked by the pitting resistance equivalent (PRE) which is defined in Eq. 2, as a function of the weight percentages of $\mathrm{Cr}$, $\mathrm{Mo}$ and $\mathrm{W} .{ }^{16-18}$ The crevice corrosion resistance of $\mathrm{Ni}-\mathrm{Cr}-\mathrm{Mo}$ and $\mathrm{Ni}-\mathrm{Cr}-\mathrm{Fe}$ alloys generally increases with $\mathrm{PRE}$, though there are some examples of changes in the alloy ranking depending on environmental conditions. ${ }^{32}$ Even though there is some criticism on the use of PRE, it is widely used as a rough indication of the localised corrosion resistance of nickel-based alloys and stainless steels. ${ }^{33}$ Table 1 lists the PRE of selected alloys.

$P R E=w t . \% C r+3.3(w t . \% M o+0.5 w t . \% W)$

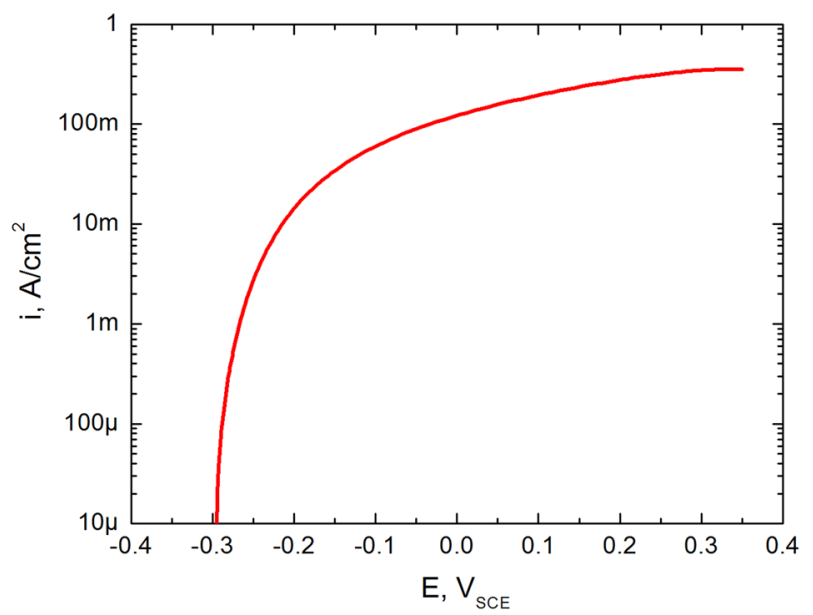

Fig. 2 Polarisation curve of alloy 825 in a pH 0.06 simulated crevice/ pit solution, at $95^{\circ} \mathrm{C}$. Reproduced with permission from ref. 24, NACE International, Houston, TX. All rights reserved. @ NACE International 1993

Criterion for crevice corrosion occurrence

Crevice corrosion is expected to occur only above a critical potential $\left(E_{\mathrm{CRIT}}\right)^{5}$. The criterion for crevice corrosion occurrence selected by YMP is that the open circuit or corrosion potential $\left(E_{\mathrm{CORR}}\right)$ must be higher than $E_{\mathrm{CRIT}}$, as stated in Eq. $3 .^{4,5}$ If the evolution of the environmental conditions in the repository over time can be anticipated and the metallurgical conditions of the alloy are known, then it is possible to apply the criteria of Eq. 3. YMP devoted significant amount of research to determine $E_{\text {CORR }}$ and $E_{\mathrm{CRIT}}$ for alloy 22 in relevant environmental and metallurgical conditions, in the Long-Term Corrosion Test Facility at Lawrence Livermore National Laboratory. ${ }^{28}$ The predicted environments in contact with the waste containers at Yucca Mountain site are naturally-aerated multi-ionic solutions, which can concentrate by evaporation due to the heat released by the radioactive waste. ${ }^{5,28}$

$E_{C O R R}>E_{C R I T}$

$E_{\mathrm{CRIT}}$ was defined as the repassivation potential of the crevice corrosion $\left(E_{\mathrm{R}, \mathrm{CREV}}\right){ }^{5}$ The extensive testing of alloy 22 led to significant improvements in the techniques and experimental setups used to determine $E_{R, C R E V}$. $E_{R, C R E V}$ was initially obtained by cyclic potentiodynamic polarisation (CPP) tests using artificially creviced specimens. $^{34-36}$ However, it was pointed out that CPP method put $\mathrm{Ni}-\mathrm{Cr}-\mathrm{Mo}$ alloys in the transpassive range of potentials where chromates and probably molybdates (both localised corrosion inhibitors) are released to the testing solution. ${ }^{37}$ Consequently, other testing methods were applied in which transpassivity was avoided by limiting the maximum applied potential or current density. The most relevant of these methods is the Tsujikawa-Hisamatsu electrochemical (THE) method and its modification, the potentiodynamic-galvanostatic-potentiodynamic (PD-GS-PD) method. ${ }^{37,38}$ In aggressive environments (high $\left[\mathrm{Cl}^{-}\right]$ and $T$ ), crevice corrosion readily occurs and the obtained $E_{\mathrm{R}, \mathrm{CREV}}$ is the same disregarding the testing technique. However, under less aggressive conditions, crevice corrosion is more difficult to initiate, and the obtained value of $E_{\mathrm{R} C \mathrm{CREV}}$ may differ substantially from one method to another. ${ }^{35}$, $37-39$ Even variations in the selected parameters of a single technique (applied current density, polarisation time, etc.) may lead to different results. It was concluded that those methods which are able to produce the initiation of crevice corrosion, but with a limited propagation, give the most conservative values of $E_{R, C R E V}$. In this regard, the PD-GS-PD technique was recommended as it renders conservative results in a relatively short testing time. ${ }^{37,} 39$ Another 
disadvantage of the classical CPP technique is the large propagation of crevice corrosion it produces. ${ }^{39}$ The crevicing device was found to be as important as the selected technique for determining $E_{\mathrm{R}, \mathrm{CREV}}{ }^{37}$ This topic will be discussed later along with metallurgical variables.

\section{Environmental variables}

Chloride concentration and temperature. Crevice corrosion of $\mathrm{Ni}-\mathrm{Cr}$-Mo alloys appears as a shiny crystalline area under the crevice formers or just adjacent to them, depending on the testing method and environment. ${ }^{31}$ As long as $\left[\mathrm{Cl}^{-}\right]$and $T$ increase, creviced corroded areas moves towards the crevice mouth and for very concentrated chloride solutions ( 5 to $10 \mathrm{~mol} / \mathrm{L}$ ) the attack occurs adjacent to crevices. ${ }^{17,} 31,40$ Grains of the alloy and even crystal planes may be discernible with the help of scanning electron microscopy (SEM). In certain thermally aged materials, the attack appears as intergranular corrosion. ${ }^{40}$ However, this type of attack may also appear at random grain boundaries in fully solubilised materials. ${ }^{41}$ Triple points show preferential attack. ${ }^{41}$ Corrosion products enriched in Mo and W are usually observed at creviced corroded sites, especially in dilute chloride solutions. ${ }^{19,}, 26,42$ These corrosion products include polymeric molydbates which are responsible of shifting the attack to adjacent sites thus producing a shallow corrosion. ${ }^{42}$ An acidified and concentrated chloride solution builds up in these active crevices. In fact, non-creviced $\mathrm{Ni}-\mathrm{Cr}-\mathrm{Mo}$ alloys corroding in hot hydrochloric acid $(\mathrm{HCl})$ show the same forms of attack (crystalline-type and intergranular corrosion). ${ }^{43}$

Groundwaters are multi-ionic solutions which are expected to concentrate due to evaporation giving way to concentrated brines. $^{5}$ Deliquescence salts may exist even at temperatures significantly higher than the boiling temperature of water $\left(\sim 155^{\circ} \mathrm{C}\right) .7,27,28,44$ Chloride, which is present in these brines, is the main deleterious species that causes crevice corrosion. Crevice corrosion occurs above the critical crevice temperature (CCT) and it is hard to initiate in $\mathrm{Ni}-\mathrm{Cr}-\mathrm{Mo}$ alloys if $\left[\mathrm{Cl}^{-}\right]$is low. ${ }^{30}$ In general, $E_{R, C R E V}$ decreases for increasing $\left[\mathrm{Cl}^{-}\right]$in a logarithmic fashion and it decreases linearly with increasing $T$. Equation 4 describes $E_{R, C R E V}$ as a function of $\left[\mathrm{Cl}^{-}\right]$and $T$ for alloys $625,22, \mathrm{C}-22 \mathrm{HS}$ and HYBRID$\mathrm{BC} 1$. The value of constants $C_{1}, C_{2}, C_{3}$ and $C_{4}$ depend on each alloy. ${ }^{17,} 29$ Saturation of $E_{R, C R E V}$ occurs above certain critical temperature. In such conditions, $E_{\mathrm{R}, \mathrm{CREV}}$ reaches a minimum value, which is the $E_{\mathrm{CORR}}$ of the alloy in the acidified crevice solution. The more resistant to crevice corrosion the alloy is the higher the temperature for this saturation. ${ }^{17}$ Figure 3 shows $E_{\mathrm{R}, \text { CREV }}$ for alloy 22 as a function of $\left[\mathrm{Cl}^{-}\right]$and $T$. The minimum $E_{\mathrm{R}, \mathrm{CREV}}$ for alloy 22 is observed at a saturation temperature of $110^{\circ} \mathrm{C} .{ }^{17}$

$$
E_{R, C R E V}=\left(C_{1}+C_{2} T\right) \log \left[C^{-}\right]+C_{3} T+C_{4}
$$

Temperature at the containers surface will rise after the repository closure due to the heat released from radioactive decay. After reaching a peak of 160 to $180^{\circ} \mathrm{C}$, temperature in the Yucca Mountain repository is expected to slowly decrease. ${ }^{4}$ There is a possibility that once crevice corrosion have started at a certain temperature, it may propagate at lower temperatures below the corresponding $E_{\mathrm{R}, \mathrm{CREV}}$. Studies in this regard indicate so far that the safety operation conditions based on $E_{R, C R E V}$ can be considered conservative. ${ }^{45}$ Consequently, alloy repassivation by slow cooling may be roughly predicted by Eq. 4 .

Potential. $E_{\text {CORR }}$ of alloy 22 in multi-ionic solutions increases significantly over time until reaching a steady state. ${ }^{28,46}$ This process was observed to occur independently of the metallurgical condition of the alloy and it is called passivity induced ennoblement. $^{7,47}$ The main cathodic reaction expected in an unsaturated repository is oxygen reduction. ${ }^{48}$ Peroxides may be

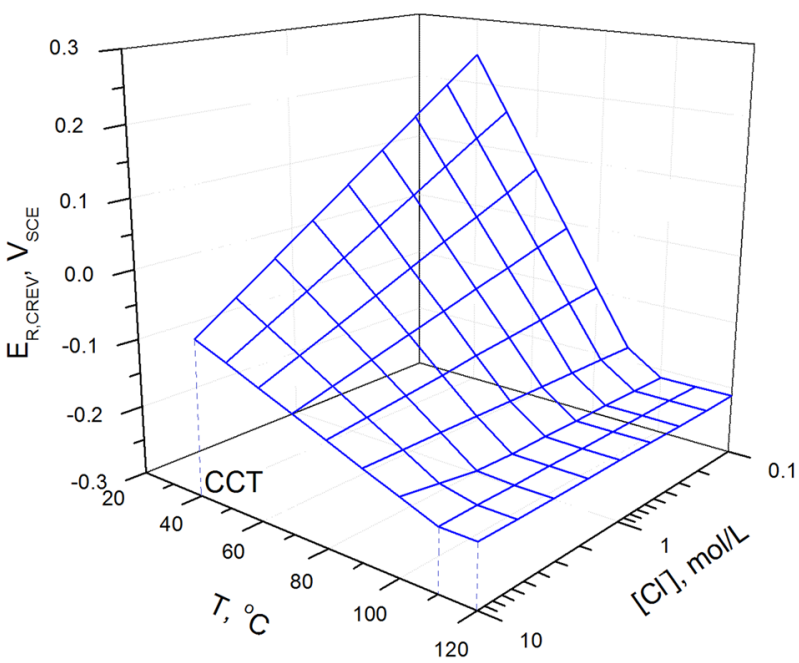

Fig. 3 Crevice corrosion repassivation potential of alloy 22 as a function of chloride concentration and temperature (data from ref. 17)

produced by water radiolysis adding another oxidising species. Water radiolysis may be precluded or minimised if a thick-walled container or an inner shielding container is used. ${ }^{11}$ In the YMP design, an inner shell of a type 316 (UNS S31600) stainless steel provides shield to radiation and mechanical integrity. ${ }^{4}$

As stated above, crevice corrosion may occur if $E_{\text {CORR }}$ of the alloy increases above its $E_{R, C R E V}$ in the service conditions. ${ }^{5}$ However, $E_{\mathrm{CORR}}>E_{\mathrm{R}, \mathrm{CREV}}$ does not necessarily lead to crevice corrosion initiation. Stability product (Eq. 1) is satisfied at $E>E_{\mathrm{R}}$, CREV only if a tight crevice forms on the alloy surface. In-service crevices may produce a wide range of diffusion paths. Potential ranges of different crevice corrosion susceptibility can be stated based on the value of the anodic current density in the acidified crevice solution. ${ }^{26}$ As long as $i$ increases, crevice corrosion will stabilise for lower values of $x$ (less tight or less demanding crevices). Figure 1 shows $i$ vs. $E$ for crevice-corroded alloy 22 in 1 $\mathrm{mol} / \mathrm{L} \mathrm{NaCl}$ at $90^{\circ} \mathrm{C}$. Low but increasing crevice corrosion susceptibility is expected in the potential range from $E_{\mathrm{R}, \mathrm{CREV}}$ to $0.25 \mathrm{~V}_{\mathrm{SCE}}$, which shows an increment of $i$ with increasing $E$. High and constant crevice corrosion susceptibility is expected at $E>$ $0.25 \mathrm{~V}_{\mathrm{SCE}}$ as $i$ remains almost constant at its highest value (Fig. 1). ${ }^{26}$

Crevice corrosion inhibitors. Groundwaters contain a wide variety of species and they may be contaminated with other species during the construction of the repository site. ${ }^{49-51}$ There is a considerable amount of research on the effect of these species as potential anodic inhibitors of chloride-induced crevice corrosion of alloy $22 .{ }^{29}, 34,36,38,44,50,52-56$ On the other hand, there is practically no research reported on the effect of the same species as cathodic inhibitors. ${ }^{57}$ Anions commonly found in groundwaters include sulphate $\left(\mathrm{SO}_{4}{ }^{2-}\right)$, carbonate/bicarbonate $\left(\mathrm{CO}_{3}{ }^{2-} / \mathrm{HCO}_{3}{ }^{-}\right)$, fluoride $\left(\mathrm{F}^{-}\right)$and nitrate $\left(\mathrm{NO}_{3}{ }^{-}\right)$. All of them act as crevice corrosion inhibitors with varying efficiencies. ${ }^{29}, 34,36,38,44,50,52$ Organic acids such as citric, acetic and oxalic might occur due to microbial activity. ${ }^{53,} 54$ Silicate $\left(\mathrm{SiO}_{3}{ }^{2-}\right)$, chromate $\left(\mathrm{CrO}_{4}{ }^{2-}\right)$, molybdate $\left(\mathrm{MoO}_{4}{ }^{2-}\right)$, tungstate $\left(\mathrm{WO}_{4}{ }^{2-}\right)$, phosphate $\left(\mathrm{PO}_{4}{ }^{3-}\right)$ have also been tested mostly for gaining insights into inhibiting mechanisms. ${ }^{52,55,56}$ $E_{\mathrm{R}, \mathrm{CREV}}$ of alloy 22 is independent of solution $\mathrm{pH}$ in a wide range of $\mathrm{pH}$ values. ${ }^{26,51}$ Complete inhibition of crevice corrosion occurs at $\mathrm{pH} \geq 12.5$ at any chloride concentration. ${ }^{55}$ Such a high $\mathrm{pH}$ value is not expected in Yucca Mountain concentrated groundwaters. ${ }^{4}$ However, repository designs which include a cementitious backfill will provide an environment with $\mathrm{pH} \approx 13$ at the waste container surface. ${ }^{8}$ 
The inhibitor to chloride concentration ratio $(R)$ is a parameter commonly used to study inhibitors efficiency (Eq. 5) ${ }^{49}$ Complete inhibition of crevice corrosion is reached at $R=R_{\mathrm{CRIT}}$, when Eq. 1 cannot be satisfied at any potential. For $R<R_{\mathrm{CRIT}}$, some inhibitors are able to produce an increase of $E_{R, C R E V}$ according to Eq. 6, where $A$ and $B$ are constants. ${ }^{52}$ Figure 4 shows a diagram indicating ranges of crevice corrosion susceptibility and protection for a nickel-based alloy in a chloride plus inhibitor solution. Figure 5 shows $R_{\mathrm{CRIT}}$ as a function of $\left[\mathrm{Cl}^{-}\right]$for mill-annealed alloy 22 tested by different methods, at $90^{\circ} \mathrm{C}^{49} R_{\mathrm{CRIT}}$ remains constant or shows a slight increase for increasing $\left[\mathrm{Cl}^{-}\right]$with the only exception of hydroxyl $\left(\mathrm{OH}^{-}\right)$. Even apparently detrimental species, such as fluoride and organic acids, behave as crevice corrosion inhibitors though their $R_{\mathrm{CRIT}}$ are large. ${ }^{36,53}$

$\mathrm{R}=[\mathrm{Inh}] /\left[\mathrm{Cl}^{-}\right]$

$\mathrm{E}_{\mathrm{R}, \mathrm{CREV}}=\mathrm{A}+\mathrm{B} \log (\mathrm{R})$

Inhibitors modify the anodic behaviour of alloy 22 in the crevice solution thus hindering the local development of a critical chemistry. ${ }^{49,50}$ They may act (1) by increasing $E_{\mathrm{CORR}}$ in the crevice solution, (2) by increasing the value of $(x \cdot i)_{\mathrm{CRIT}}$, and/or (3) by increasing the resistance of a salt film locally formed on the alloy surface. $^{49}$

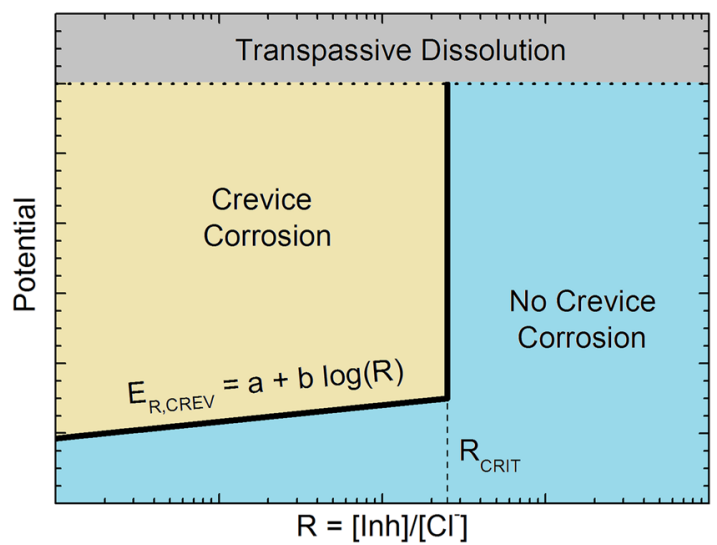

Fig. 4 Ranges of crevice corrosion susceptibility and protection for a $\mathrm{Ni}-\mathrm{Cr}-\mathrm{Mo}$ alloy in a chloride plus inhibitor solution. Reprinted from ref. 52 with permission from Elsevier
Nitrate stands out among groundwater inhibitors due to its high concentration in Yucca Mountain groundwater and its remarkable inhibiting efficiency. ${ }^{28,} 29,34,44,52,58,59$ Nitrate shows $R_{\text {CRIT }}$ values from 0.1 to 0.5 for alloy 22 , in different testing conditions. Sulphate and carbonate, for instance, shows $R_{\mathrm{CRIT}}$ values from 1 to 2 in similar testing conditions. ${ }^{52,60}$ Phosphate is such an efficient inhibitor as nitrate but it is not generally found in groundwater. ${ }^{56}$ Predictions of crevice corrosion inhibition based on $\mathrm{R}$ have been discouraged, as bacteria and fungi can reduce or assimilate anions, such as nitrate and sulphate, altering the relative concentration of anions. ${ }^{61}$

\section{Metallurgical variables}

Container surface condition and crevice geometry. Surface finishing of waste containers will affect the geometry of potential crevices. Surface roughness and defects along with debris and deposits will determine the geometrical characteristics of crevices. The classical bi-dimensional concept of a crevice is defined by its length and gap (mouth opening). ${ }^{62,}{ }^{63}$ However, in-service crevices are more likely to be interconnected microcrevices. The preferred specimen in crevice corrosion testing is a prism or multiple crevice assembly. ${ }^{28,34,37,38,44}$ This specimen contains a hole through which a nut-and-bolt system adjusts a couple of ceramic crevice formers on the alloy surface. The crevice formers are previously wrapped with PTFE tape of $70 \mu \mathrm{m}$ thickness. This thick PTFE tape fills the gaps between the ceramic crevice former and the alloy producing tiny microcrevices. In such testing conditions, $E_{\mathrm{R} C \mathrm{REV}}$ becomes independent of specimen surface roughness. ${ }^{37}$ On the other hand, solid PTFE crevice formers and ceramic formers not wrapped with PTFE tape lead to poor reproducibility of results or no crevice corrosion initiation for alloy $22 .{ }^{26,37}$ Surface roughnesses of the specimen and crevice formers become important if crevice formers are not wrapped with PTFE tape. In these cases, crevice corrosion initiation is easier the smoother the surfaces are. ${ }^{64}$ An applied torque higher than $2 \mathrm{~N} \cdot \mathrm{m}$ is necessary for ensuring good reproducibility of tests using PTFEwrapped ceramic crevice formers. ${ }^{37}$ Solid polymeric crevice formers are usually torqued to $0.35 \mathrm{~N} \cdot \mathrm{m}$ to avoid their excessive deformation. $^{30}$

Thermal ageing. Figure 6 shows a time-temperature transformation diagram for alloy 22 (base metal). The effect of different thermal-ageing treatments on crevice corrosion susceptibility of $\mathrm{Ni}-\mathrm{Cr}-\mathrm{Mo}$ alloys has been studied in some detail, especially for alloy $22 .{ }^{30,40,65,66}$ Alloy C-4 shows the best thermal stability

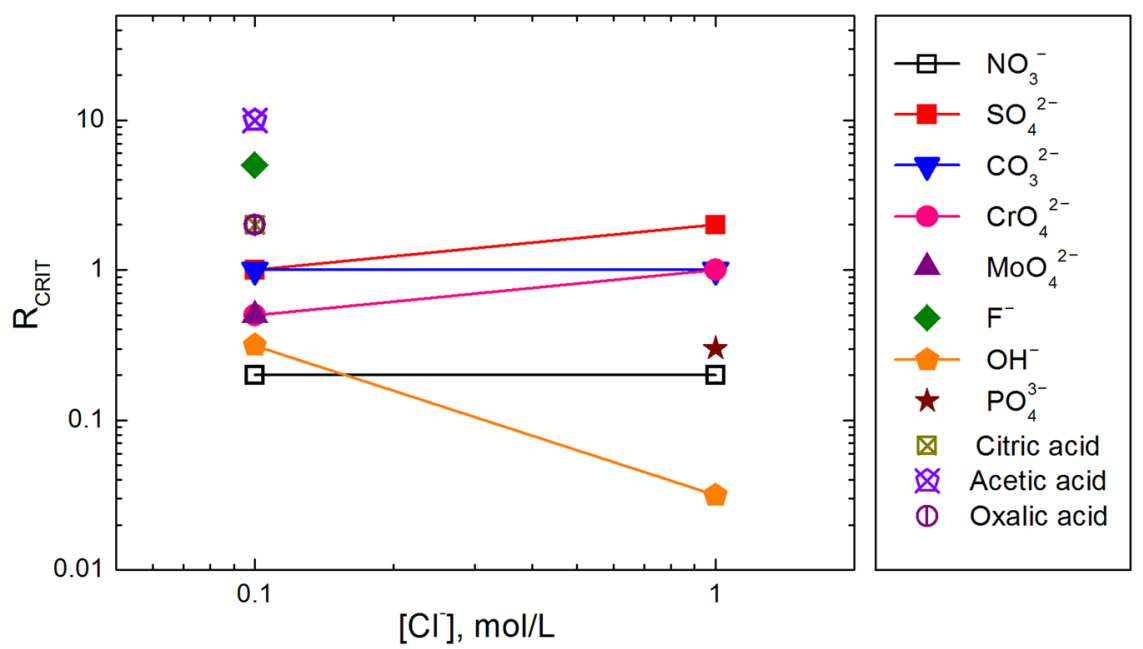

Fig. 5 Critical inhibitor to chloride concentration ratio for different inhibitors as a function of chloride concentration for mill-annealed alloy 22, at $90^{\circ} \mathrm{C}$. Reproduced from ref. 49 with permission, copyright 2012 De Gruyter 


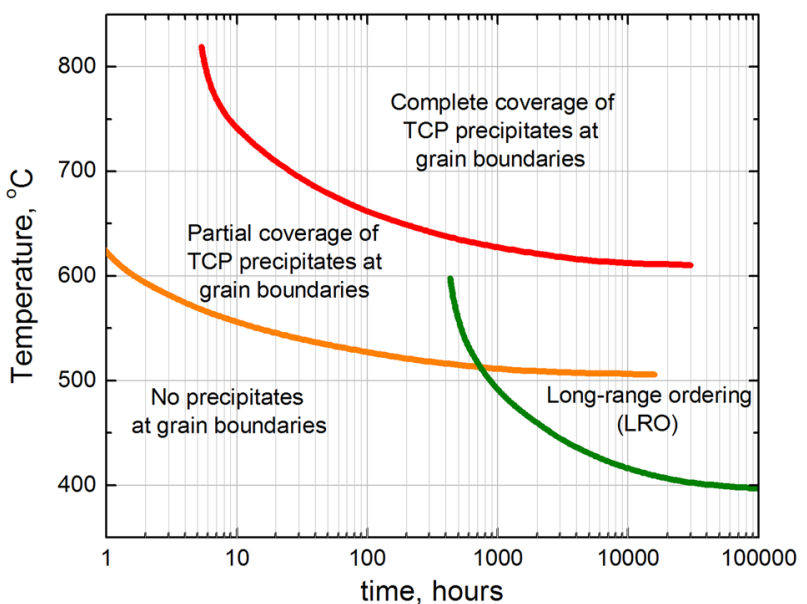

Fig. 6 Isothermal time-temperature transformation diagram for alloy 22. Adapted from ref. 4, Department of Energy 2001

among Ni-Cr-Mo alloys. ${ }^{15}$ Thermal ageing for up to $40,000 \mathrm{~h}$ at temperatures below $427^{\circ} \mathrm{C}$ does not affect any mechanical or corrosion property of $\mathrm{Ni}-\mathrm{Cr}-\mathrm{Mo}$ alloys. ${ }^{67}$ Above $427^{\circ} \mathrm{C}$, a longrange ordering reaction (LRO) occurs producing an ordered $\mathrm{Ni}_{2}(\mathrm{Cr}$, Mo) phase. ${ }^{68}$ The LRO transformation is slow for alloy 22 but faster for alloy $\mathrm{C}-22 \mathrm{HS}$, which can be age-hardened to double its yield strength by a two-stage heat treatment in $48 \mathrm{~h}^{69}$ Homogeneous precipitation of this ordered phase does not affect the localised corrosion susceptibility of $\mathrm{Ni}-\mathrm{Cr}-\mathrm{Mo}$ alloys. ${ }^{70}$ Topologically closepacked (TCP) phases, such as $\mu, \sigma$ and $P$, precipitate at higher temperatures. ${ }^{68,71,72}$ Precipitation of TCP phases starts at grain boundaries above $593^{\circ} \mathrm{C}$ for alloy 22 . This process may lead to alloy sensitisation to intergranular corrosion as TCP phases are rich in $\mathrm{Mo}$ and/or $\mathrm{Cr}$, and adjacent zones are depleted in these alloying elements. $^{68,71,72}$ Sensitisation by carbide precipitation is not observed in modern $\mathrm{Ni}-\mathrm{Cr}-\mathrm{Mo}$ alloys. ${ }^{72}$ Age-hardened alloy C$22 \mathrm{HS}$ is slightly less resistant to crevice corrosion than fully solubilised material but it is as resistant as mill-annealed alloy $22 .^{66}$ Currently, there is no agreement on the effect of precipitation of TCP phases on crevice corrosion resistance of alloy 22. Some authors report a detrimental effect, ${ }^{30,65}$ whereas others report a negligible effect. ${ }^{28,} 40,51,66$ These apparently contradicting researches are based on different testing techniques and crevice former materials (solid PTFE vs. PTFE-wrapped ceramic). Crevice geometry may be the main cause of reported differences. The tighter the crevice is the lower the current density needed for crevice corrosion stabilisation is. It may be speculated that the anodic response of solubilised and thermally aged material is similar at low current densities (PTFE-wrapped ceramic crevice formers) $)^{28,40,51,66}$ but differ at high current densities (solid PTFE crevice formers). ${ }^{30,65}$

Container fabrication processes. Fabrication processes of the YMP waste container include longitudinal welding of alloy 22 hot-rolled cylinders. Multiple cylinders are welded together circumferentially to achieve the require container length. Then, the bottom lid is welded to the cylinder. The selected welding process is gas tungsten arc welding (GTAW) using alloy 622 weld filler (AWS A5.14 ERNiCrMo-10). After welding operations, solution annealing is performed at $1150^{\circ} \mathrm{C}$ followed by water quenching to remove residual stresses. Once the waste is put within the container, dual closure lids will be welded on top. Laser peening or low plasticity burnishing are used to mitigate residual stresses in the outer closure lid., 30, 65, 73

As-welded alloy 22 shows a dendritic structure with TCP phases in the interdendritic regions. Post-weld heat treatments produce an increase in the amount and size of TCP precipitates in the welded material, which increases with both aging time and temperature. $^{65}$ Solution-annealing treatments can mitigate TCP precipitation in heat-affected zones but they are not completely effective in dissolving TCP precipitates in weldments. ${ }^{73}$ Fabrication processes are assumed to extend the range of environmental conditions for crevice corrosion occurrence on alloy 22 to lower $\left[\mathrm{Cl}^{-}\right]$, lower $\mathrm{T}$, lower $\mathrm{E}$ and higher $\mathrm{R}$ for inhibitors. ${ }^{30,} 65$ However, as discussed above for the case of TCP precipitation in thermally aged alloy 22, contradicting results are reported by different research groups. $28,35,44$

There is limited information on the influence of bright and black annealing on crevice corrosion susceptibility of $\mathrm{Ni}-\mathrm{Cr}-\mathrm{Mo}$ alloys. ${ }^{27}, 66,74$ Black-annealing oxide from a solution heat treatment at $1121{ }^{\circ} \mathrm{C}$ for $20 \mathrm{~min}$ followed by water quenching does not affect crevice corrosion resistance of alloy $22 .{ }^{74}$ There is some evidence of a beneficial effect of the black annealed film in long-term immersion tests. ${ }^{27}$ Efforts to apply the PD-GS-PD technique to alloy 22 and alloy $\mathrm{C}-22 \mathrm{HS}$ with the native oxide from different heat treatments were unsuccessful. However, specimens with native oxide were less attacked than polished specimens. ${ }^{66}$

\section{Crevice corrosion in saturated repositories}

Crevice corrosion studies of nickel-based alloys for saturated repositories are limited. Alloys 22, 625, 825 and C-4 have been considered as corrosion-resistant barriers for the German and Belgian waste disposal programmes. ${ }^{6}$ The natural barrier of the German programme is a dry rock salt formation. Laboratory tests have been performed in concentrated salt brines containing $\mathrm{Cl}^{-}$, $\mathrm{SO}_{4}{ }^{2-}, \mathrm{Na}^{+}, \mathrm{K}^{+}, \mathrm{Ca}^{2+}$ and $\mathrm{Mg}^{2+}$. The German concept involves the disposal of nuclear spent fuel within a carbon steel cask surrounded by a corrosion-protection layer. This protection layer is applied by surface welding. Alloy C-4 outperformed alloys 825 and 625 with regard to pitting and crevice corrosion resistance in selected brines. Tests in $\mathrm{MgCl}_{2}$-rich brine at temperatures up to $170^{\circ} \mathrm{C}$ showed that alloy C-4 is prone to crevice corrosion. This susceptibility increases with increasing temperature and with the addition of $\mathrm{H}_{2} \mathrm{~S}$ to the media. A thermal stress relief treatment of the material was recommended to improve the corrosion resistance of the welded alloy C-4 in the presence of sulphides. Long-term in situ corrosion experiments were performed in the Asse salt mine (Germany) simulating normal disposal conditions. Although the alloys C -4 and 22 showed an overall good corrosion resistance, they were discarded as it is expected their failure by localised corrosion under more aggressive conditions. ${ }^{6}$

The current Belgian concept for underground disposal of highlevel nuclear waste is a supercontainer made of carbon steel and surrounded by a thick concrete buffer. ${ }^{75}$ Boom clay is the considered host rock. Former corrosion studies involved nickelbased alloys such as alloys C-4 and 22 tested in synthetic oxidised Boom clay water and bentonite water. These alloys did not suffer localised corrosion at temperatures up to $90^{\circ} \mathrm{C}$. However, crevice corrosion occurred at $140^{\circ} \mathrm{C}$ in solutions with $\left[\mathrm{Cl}^{-}\right]$from 20 to $50 \mathrm{~g} / \mathrm{L}^{6}$.

\section{Recent works and criticism}

The criterion of $E_{\mathrm{CORR}}<E_{\mathrm{R}, \mathrm{CREV}}$ for avoiding crevice corrosion occurrence, at any time in the required container lifetime, has been considered to be over-conservative by many researchers. ${ }^{76}$ There are documented situations in which crevice corrosion will not proceed at $E>E_{R, C R E V}$, and even if it starts, its self-limited propagation will avoid complete penetration of the container wall. $^{77,} 78$ Points of criticism to this criterion are summarised below.

- Type of crevice: as previously discussed, in-service crevices may be significantly less 'demanding' than those used in laboratory testing. The crevices occurring on container 
surfaces at repository sites have not been characterised.

- Cathodic inhibition: passive films, spontaneously developed on $\mathrm{Ni}-\mathrm{Cr}-\mathrm{Mo}$ alloys, inhibit oxygen reduction; this is a cathodic reaction necessary for crevice corrosion to occur oxidising environments. Repassivation of passive alloys results from slow reduction of oxygen on passive films. ${ }^{48,} 78,79$

- Cathodic limitations: cathodic sites must be electrically connected by a continuous aqueous film to the crevice site to serve as cathodes. Low effective cathode-to-anode areas will limit the cathodic current needed to sustain crevice corrosion.

- Stifling: crevice corrosion of alloy 22 stifles after some propagation both in galvanically-coupled and potentiostatic conditions. $^{19,64}$ Severity of geometrical conditions in a crevice decreases as localised corrosion progresses. ${ }^{39}$

- Shallow attack: formation of polymeric molybdates in crevicecorroded $\mathrm{Ni}-\mathrm{Cr}-\mathrm{Mo}$ alloys produce the shift of propagation to areas unprotected by molybdate layers thus producing a shallow attack. ${ }^{42,80}$

- Thin films: in early stages of crevice corrosion initiation, a thin film of electrolyte solution may be more detrimental than bulk solutions because it can transport a higher amount of oxygen to the alloy surface. ${ }^{31}$ However, a thin film of solution is not able to sustain crevice corrosion growth because corrosion products remain at the crevice site and therefore act as a physical barrier for further growth. ${ }^{81}$

All the points listed above lead to the conclusion that even if crevice corrosion of alloy 22 (or other $\mathrm{Ni}-\mathrm{Cr}$-Mo alloy) container material occurs its limited propagation will grant a longer period of nuclear waste containment. Perforation of the container is not the immediate consequence of the condition $E_{\mathrm{CORR}}>E_{\mathrm{R}, \mathrm{CREV}}$.

Crevice corrosion testing under potential control does not take into account cathodic limitations. In-service conditions are better simulated by galvanostatic, galvanically-coupled or open circuit tests. Under such conditions, crevice corrosion may start after an initial period characterised by a potential increase. Then potential lowers and stabilises after reaching a peak. ${ }^{19,} 48,77,78,82$ Galvanostatic tests show that this stable potential of crevice corrosion propagation does not depend on the applied current but on the alloy composition. As long as the molybdenum content of the alloy increases, the attack is shallower. ${ }^{19}$ This is attributed to the effect of polymeric molybdates, which occurs more rapidly as wt. \% Mo of the alloy increases. For alloy HYBRID-BC1 (22 wt. \% Mo), crevice corrosion attack becomes wider but shallower (less penetration) as long as the galvanostatic current increases. ${ }^{82}$ Crevice is able to remain active form some time after the applied current is reduced to zero indicating that propagation can be maintained by proton reduction within the crevice. ${ }^{19,} 82$

The criterion of $E_{\mathrm{CORR}}<E_{\mathrm{R}, \mathrm{CREV}}$ is robust for ruling out crevice corrosion in conditions where $E_{\mathrm{R}, \mathrm{CREV}}$ is much higher than $E_{\mathrm{CORR}}$ in the environmental and metallurgical conditions of alloy service. This may be the case of saturated repositories where the main oxidising species is proton. In unsaturated repositories, this criterion is hard to be met even for the most corrosion-resistant alloys. However, penetration of the container at $E_{\mathrm{CORR}}>E_{\mathrm{R}, \mathrm{CREV}}$ will only occur if many conditions are fulfilled at the same time (tight crevice, cathodic current, deep attack, etc.). A less conservative criterion, which takes into account these conditions is necessary for unsaturated repositories.

\section{CONCLUSIONS}

Nickel-based alloys are considered as engineering barriers of geological repositories. There is a significant amount of research supporting the use of these alloys for the corrosion-resistant layer of nuclear waste containers. However, crevice corrosion is an important degradation process that may limit the lifetime of containers in the timeframe of decades or centuries. Crevice corrosion resistance of nickel-based alloys in repository environments depends on environmental and metallurgical variables. The effect of these variables has been studied in some detail, particularly for alloy 22. Crevice corrosion susceptibility increases with increasing chloride concentration and temperature. Other species present in groundwaters are considered beneficial with different efficiencies as inhibitors. Container fabrication processes, such as welding and post-welding treatments, may increase the crevice corrosion susceptibility of the nickel-based alloys, though there is no agreement in the literature in this regard.

The present criterion for crevice corrosion occurrence in repository environments is that crevice corrosion will occur if the corrosion potential of the alloy is higher than a critical potential, which is defined as the crevice corrosion repassivation potential. This is a robust criterion for ruling out crevice corrosion in saturated repositories. However, the development of a less conservative criterion for crevice corrosion occurrence is necessary to use these alloys in unsaturated repositories. A number of points have been raised to indicate why the present criterion for avoiding crevice corrosion may be over-conservative, based on understanding in corrosion science to date. Even though the criterion offers a fixed value for $E_{R, C R E V}$, the concept of fixed value, as in the case of $E_{\text {CORR, }}$, does not reflect the reality that such potentials will evolve with time, temperature, and any other environmental or metallurgical factors that may alter in the course of centuries. Corrosion is a complex kinetic process, and does not 'switch' at fixed (or readily predetermined) values of potential ( $\left.E_{R, C R E V}\right)$ from passivity to crevice corrosion. Therefore, the proposal of a minimum $E_{\mathrm{R}, \mathrm{CREV}}$ for the most aggressive conditions that take into account changes in temperature and the principal environmental factors, is a practical over-conservative criteria below, which no crevice corrosion would be possible.

\section{ACKNOWLEDGEMENTS}

Financial support from the Argentine Agencia Nacional de Promoción Científica y Tecnológica of the Ministerio de Ciencia, Tecnología e Innovación Productiva is acknowledged.

\section{AUTHOR CONTRIBUTIONS}

R. M. C. and M. A. R. participated in the conception, design, drafting, and revision of the manuscript.

\section{ADDITIONAL INFORMATION}

Competing interests: The authors declare no competing financial interests.

Publisher's note: Springer Nature remains neutral with regard to jurisdictional claims in published maps and institutional affiliations.

\section{REFERENCES}

1. IAEA. General Safety Guide No. GSG-1: Classification of Radioactive Waste (IAEA, 2009).

2. IAEA. Technical Report Series No. 413, Scientific and Technical Basis for the Geological Disposal of Radioactive Wastes (IAEA, 2003).

3. Witherspoon, P. A. \& Bodvarsson, G. S (eds). Geological Challenges in Radioactive Waste Isolation: Third Worldwide Review (Lawrence Berkeley National Laboratory, 2001).

4. U.S. Department of Energy, Office of Civilian Radioactive Waste Management. DOE/RW-0539, Yucca Mountain Science and Engineering Report. (DOE, 2001).

5. Gordon, G. M. Speller award lecture:corrosion considerations related to permanent disposal of high-level radioactive waste. Corrosion 58, 811-825 (2002).

6. Kursten, B. et al. COBECOMA: State-of-the-art document on the COrrosion BEhaviour of COntainer MAterials. European Commission 5th Euratom Framework Programme, 1998-2002. Contract \#FIKW-CT-20014-20138 Final Report (European Commission, 2004) 
7. Shoesmith, D. W. Assessing the corrosion performance of high-level nuclear waste containers. Corrosion 62, 703-722 (2006).

8. King, F. Container materials for the storage and disposal of nuclear waste. Corrosion 69, 986-1011 (2013).

9. Gras, J.-M. Life prediction for HLW containers-issues related to long-term extrapolation of corrosion resistance. C. R. Phys. 3, 891-902 (2002).

10. Hultquist, G. et al. Hydrogen gas production during corrosion of copper by water. Corros. Sci. 53, 310-319 (2011).

11. Rodríguez, M. A. Anticipated degradation modes of metallic engineered barriers for high-level nuclear waste repositories. JOM 66, 503-525 (2014).

12. Galvele, J. R. Tafel's law in pitting corrosion and crevice corrosion susceptibility. Corros. Sci. 47, 3053-3067 (2005).

13. Alves, H. \& Heubner, U. Aqueous Corrosion of Nickel and its Alloys: Shreir's Corrosion 1 (Elsevier Ltd., 2010).

14. Agarwal, D. C. \& Sridhar, N. Uhlig's Corrosion Handbook 837-852 (John Wiley \& Sons, Inc., 2011). .

15. Rebak, R. B. in Material Science and Engineering. A Comprehensive Treatment (eds. Cahn, R. W., Haasen, P. \& Kramer, E. J.) 69-111 (Wiley-VCH, 2000).

16. Zadorozne, N. S., Giordano, C. M., Rodríguez, M. A., Carranza, R. M. \& Rebak, R. B. Crevice corrosion kinetics of nickel alloys bearing chromium and molybdenum. Electrochim. Acta 76, 94-101 (2012).

17. Hornus, E. C., Giordano, C. M., Rodríguez, M. A., Carranza, R. M. \& Rebak, R. B. Effect of temperature on crevice corrosion susceptibility of nickel alloys containing chromium and molybdenum. J. Electrochem. Soc. 162, C105-C113 (2015).

18. Mishra, A. K. \& Shoesmith, D. W. Effect of alloying elements on crevice corrosion inhibition of nickel-chromium-molybdenum- tungsten alloys under aggressive conditions: an electrochemical study. Corrosion 70, 721-730 (2014).

19. Ebrahimi, N., Jakupi, P., Noel, J. J. \& Shoesmith, D. W. The role of alloying elements on the crevice corrosion behaviour of Ni-Cr-Mo alloys. Corrosion 71, 1441-1451 (2015).

20. King, F. Factors in the selection of container materials for the disposal of HLW/SF. MRS Proc. 1475, 1-12 (2012)

21. King, F. \& Padovani, C. Review of the corrosion performance of selected canister materials for disposal of UK HLW and / or spent fuel. Corros. Eng. Sci. Technol. 46, 82-90 (2011).

22. Szklarska-Smialowska, Z. Pitting and Crevice Corrosion. (NACE International, 2005).

23. Galvele, J. R. Transport processes and the mechanism of pitting of metals. J. Electrochem. Soc. 123, 464-474 (1976).

24. Sridhar, N. \& Cragnolino, G. A. Applicability of repassivation potential for longterm prediction of localized corrosion of alloy 825 and type $316 \mathrm{~L}$ stainless steel. Corrosion 49, 885-894 (1993).

25. Sridhar, N. \& Dunn, D. S. Effect of applied potential on changes in solution chemistry inside crevices on type 304 I stainless steel and alloy 825 . Corrosion 50, 857-872 (1994)

26. Rodríguez, M. A., Carranza, R. M. \& Rebak, R. B. Effect of potential on crevice corrosion kinetics of alloy 22. Corrosion 66, 15007-1-15007-14 (2010).

27. Rodríguez, M. A., Stuart, M. L. \& Rebak, R. B. Long term electrochemical behavior of crevice and non-creviced alloy 22 in $\mathrm{CaCl}_{2}+\mathrm{Ca}\left(\mathrm{NO}_{3}\right)_{2}$ brines at $155^{\circ} \mathrm{C}$. Corrosion 1-22 (2007).

28. Rebak, R. B. Corrosion testing of nickel and titanium alloys for nuclear waste disposition. Corrosion 65, 252-271 (2009).

29. Dunn, D. S., Pan, Y.-M., Yang, L. \& Cragnolino, G. A. Localized corrosion susceptibility of alloy 22 in chloride solutions: part 1-mill-annealed condition. Corrosion 61, 1078-1085 (2005).

30. Dunn, D. S., Pan, Y.-M., Yang, L. \& Cragnolino, G. A. Localized corrosion susceptibility of alloy 22 in chloride solutions: part 2-effect of fabrication processes. Corrosion 62, 3-12 (2006).

31. Rebak, R. B. Factors affecting the crevice corrosion susceptibility of alloy 22. Corrosion 2005 1-17 (2005).

32. Sosa, H. S., Rodríguez, M. A., Carranza, R. M. \& Rebak, R. B. Effect of alloy composition on the crevice corrosion resistance of nickel alloys. Corrosion 1-10 (2012).

33. Mishra, A. K. \& Shoesmith, D. W. Effect of alloying elements on crevice corrosion inhibition of nickel-chromium-molybdenum-tungsten alloys under aggressive conditions: an electrochemical study. Corrosion 70, 721-730 (2014).

34. Kehler, B. A., llevbare, G. O. \& Scully, J. R. Crevice corrosion stabilization and repassivation behavior of alloy 625 and alloy 22. Corrosion 57, 1042-1065 (2001).

35. Evans, K. J. et al. Using electrochemical methods to determine alloy 22's crevice corrosion repassivation potential. JOM J. Miner. Met. Mater. 57, 56-61 (2005).

36. Carranza, R. M., Rodríguez, M. A. \& Rebak, R. B. Effect of fluoride ions on crevice corrosion and passive behavior of alloy 22 in hot chloride solutions. Corrosion 63, 480-490 (2007).

37. Giordano, C. M., Rincón Ortíz, M., Rodríguez, M. A., Carranza, R. M. \& Rebak, R. B. Crevice corrosion testing methods for measuring repassivation potential of alloy 22. Corros. Eng. Sci. Technol. 46, 129-133 (2011).
38. Mishra, A. K. \& Frankel, G. S. Crevice corrosion repassivation of alloy 22 in aggressive environments. Corrosion 64, 836-844 (2008).

39. Rincón, O. M., Rodríguez, M. A., Carranza, R. M. \& Rebak, R. B. Determination of the crevice corrosion stabilization and repassivation potentials of a corrosionresistant alloy. Corrosion 66, 105002-1-105002-12 (2010).

40. Carranza, R. M., Rodríguez, M. A. \& Rebak, R. B. Anodic and cathodic behavior of mill annealed and topologically closed packed alloy 22 in chloride solutions. Corrosion 1-25 (2008).

41. Jakupi, P., Noël, J. J. \& Shoesmith, D. W. Intergranular corrosion resistance of $\Sigma 3$ grain boundaries in alloy 22. Electrochem. Solid-State Lett. 13, C1 (2010).

42. Jakupi, P., Wang, F., Noël, J. J. \& Shoesmith, D. W. Corrosion product analysis on crevice corroded alloy-22 specimens. Corros. Sci. 53, 1670-1679 (2011).

43. Rodríguez, M. A., Carranza, R. M. \& Rebak, R. B. Passivation and depassivation of alloy 22 in acidic chloride solutions. J. Electrochem. Soc. 157, C1-C8 (2010).

44. Lian, T., Gdowski, G. E., Hailey, P. D. \& Rebak, R. B. Crevice corrosion resistance of alloy 22 in high-nitrate, high-temperature dust deliquescence environments. Corrosion 64, 613-623 (2008).

45. Hornus, E. C., Rodríguez, M. A., Carranza, R. M. \& Rebak, R. B. Effect of temperature on the repassivation kinetics of crevice-corroded nickel base alloys Edgar. Corrosion 1-15 (2015).

46. Rybalka, K. V., Beketaeva, L. A. \& Davydov, A. D. Effect of self-passivation on the electrochemical and corrosion behaviour of alloy $\mathrm{C}-22$ in $\mathrm{NaCl}$ solutions. Corros. Sci. 54, 161-166 (2012).

47. Rodríguez, M. A. \& Carranza, R. M. properties of the passive film on alloy 22 in chloride solutions obtained by electrochemical impedance. J. Electrochem. Soc. 158, C221-C230 (2011).

48. Jakupi, P., Noel, J. J. \& Shoesmith, D. W. Crevice corrosion initiation and propagation on alloy-22 under galvanically-coupled and galvanostatic conditions. Corros. Sci. 53, 3122-3130 (2011)

49. Rodríguez, M. A. Inhibition of localized corrosion in chromium containing stainless alloys. Corros. Rev. 30, 19-32 (2012).

50. Rebak, R. B. Mechanisms of inhibition of crevice corrosion in alloy 22. in Scientific Basis for Nuclear Waste Management XXX, Vol. 985 (Materials Research Society, 2006)

51. Carranza, R. M. The crevice corrosion of alloy 22 in the Yucca Mountain nuclear waste repository. JOM J. Miner. Met. Mater. 58-65 (2008).

52. Rincón Ortíz, M., Rodríguez, M. A., Carranza, R. M. \& Rebak, R. B. Oxyanions as inhibitors of chloride-induced crevice corrosion of Alloy 22. Corros. Sci. 68, 72-83 (2013).

53. Carranza, R. M., Giordano, C. M., Rodríguez, M. A. \& Rebak, R. B. Effect of organic acid additions on the general and localized corrosion susceptibility of alloy 22 in chloride solutions. Corrosion 1-20 (2008).

54. Day, S. D. et al. Corrosion behavior of alloy 22 in oxalic acid and sodium chloride solutions. Corrosion 60, 804-814 (2004)

55. Carranza, R. M., Rincón Ortíz, M., Rodríguez, M. A. \& Rebak, R. B. Corrosion resistance of alloy 22 in chloride and silicate solutions. In 14th International Conference on Environmental Degradation of Materials in Nuclear Power SystemsWater Reactors (American Nuclear Society, 2009).

56. Miyagusuku, M., Carranza, R. M. \& Rebak, R. B. Inhibition mechanism of phosphate ions on chloride-induced crevice corrosion of alloy 22. Corrosion 71, 574-584 (2015).

57. Rincón, O M., Rodríguez, M. A. \& Carranza, R. M. Effect of crevice corrosion inhibitors on the passivity of alloy 22. J. Electrochem. Soc. 159, C469-C475 (2012).

58. Gray, J. J., Hayes, J. R., Gdowski, G. E. \& Orme, C. A. Inhibiting effects of nitrates on the passive film breakdown of alloy 22 in chloride environments. J. Electrochem. Soc. 153, B156 (2006).

59. llevbare, G. O. et al. Effect of nitrate on the repassivation potential of alloy 22 in chloride-containing environments. J. Electrochem. Soc. 152, B547-B554 (2005).

60. llevbare, G. O. Effect of sulfate on the passive and crevice corrosion properties of alloy 22 in 4M sodium chloride. Corrosion 62, 340-356 (2006).

61. Little, B. J. A perspective on the use of anion ratios to predict corrosion in Yucca Mountain. Corrosion 59, 701-704 (2003).

62. Alavi, A. \& Cottis, R. A. The determination of $\mathrm{pH}$, potential and chloride concentration in corroding crevices on 304 stainless steel and 7475 aluminium alloy. Corros. Sci. 27, 443-451 (1987).

63. Oldfield, J. W. \& Sutton, W. H. Crevice corrosion of stainless steels: I. A mathematical model. Br. Corros. J. 13, 13-22 (1978).

64. Shan, X. \& Payer, J. H. Effect of polymer and ceramic crevice forme rs on the crevice corrosion of Ni-Cr-Mo Alloy 22. Corrosion 66, 105005-105014 (2010)..

65. Dunn, D. et al. The localized corrosion resistance and mechanical properties of alloy 22 waste package outer containers. JOM Miner. Met. Mater. Soc. 57, 49-55 (2005). 
66. Zadorozne, N. S., Rodríguez, M. A., Carranza, R. M., Meck, N. S. \& Rebak, R. B. Corrosion resistance of $\mathrm{Ni}-\mathrm{Cr}-\mathrm{Mo}$ and $\mathrm{Ni}-\mathrm{Mo}-\mathrm{Cr}$ alloys in different metallurgical conditions. Corrosion 1-32 (2010).

67. Rebak, R. B. \& Koon, N. E. Localized corrosion resistance of high nickel alloys as candidate materials for nuclear waste repository. Effect of alloy and weldment aging at $427^{\circ} \mathrm{C}$ for up to 40,000 h. Corrosion 1-13 (1998)

68. Tawancy, H. M., Herchenroeder, R. B. \& Asphahani, A. I. High-performance Ni-CrMo-W alloys. JOM 35, 37-43 (1983).

69. Lu, Y. L., Pike, L. M., Brooks, C. R., Liaw, P. K. \& Klarstrom, D. L. Strengthening domains in a Ni-21Cr-17Mo alloy. Scr. Mater. 56, 121-124 (2007).

70. Rebak, R. B., Koon, N. E., Dillman, J. R. \& Crook, P. Influence of aging on microstructure, mechanical properties, and corrosion resistance of a $\mathrm{Ni}-22 \mathrm{Cr}-13 \mathrm{Mo}-3 \mathrm{~W}$ Alloy. Corrosion 1-16 (2000).

71. Tawancy, H. M. Precipitation characteristics of $\mu$-phase in wrought nickel-base alloys and its effect on their properties. J. Mater. Sci. 31, 3929-3936 (1996).

72. Heubner, U. L., Altpeter, E., Rockel, M. B. \& Wallis, E. Electrochemical behavior and its relation to composition and sensitization of NiCrMo alloys in ASTM G-28 solution. Corrosion 45, 249-259 (1989).

73. Pan, Y.-M., Dunn, D. S. \& Cragnolino, G. A. Topologically close-packed phase precipitation and thermal stability in alloy 22. Metall. Mater. Trans. A 36, 1143-1151 (2005).

74. Rebak, R. B., Etien, R. A., Gordon, S. R. \& llevbare, G. O. Influence of black annealing oxide scale on the anodic behavior of Alloy 22. Corrosion 62, 967-980 (2006).

75. Kursten, B. et al. Review of corrosion studies of metallic barrier in geological disposal conditions with respect to Belgian supercontainer concept. Corros. Eng. Sci. Technol. 46, 91-97 (2011).

76. Mennecart, T., Cachoir, C. \& Lemmens, K. UO2 dissolution in high pH conditions of the Belgian Supercontainer. In MRS Symposium Proceedings. Scientific Basis for Nuclear Waste Management XXXV, Buenos Aires, Argentina, 2-7 October 2011/Materials Research Society, USA 293-298 (Cambridge University Press, 2012).
77. He, X., Dunn, D. S. \& Csontos, A. A. Corrosion of similar and dissimilar metal crevices in the engineered barrier system of a potential nuclear waste repository. Electrochim. Acta 52, 7556-7569 (2007).

78. Rodríguez, M. A., Carranza, R. M. \& Rebak, R. B. Crevice corrosion of alloy 22 at open circuit potential in chloride solutions at $90^{\circ} \mathrm{C}$. Corrosion 1-21 (2009).

79. Ungaro, M. L., Rodríguez, M. A., Carranza, R. M. \& Rebak, R. B. Electrochemical noise study of chloride-induced crevice corrosion on $\mathrm{Ni}-\mathrm{Cr}$-Mo alloys. Corrosion 1-13 (2014).

80. Jakupi, P., Noël, J. J. \& Shoesmith, D. W. The evolution of crevice corrosion damage on the $\mathrm{Ni}-\mathrm{Cr}-\mathrm{Mo}-\mathrm{W}$ alloy-22 determined by confocal laser scanning microscopy. Corros. Sci. 54, 260-269 (2012).

81. Payer, J. H. \& Kelly, R. G. Perspectives on localized corrosion in thin layers of particulate. MRS Proc. 985, 237-248 (2006).

82. Ebrahimi, N., Noël, J. J., Rodríguez, M. A. \& Shoesmith, D. W. The self-sustaining propagation of crevice corrosion on the hybrid $\mathrm{BC} 1 \mathrm{Ni}-\mathrm{Cr}-\mathrm{Mo}$ alloy in hot saline solutions. Corros. Sci. 105, 58-67 (2016).

(i) Open Access This article is licensed under a Creative Commons Attribution 4.0 International License, which permits use, sharing, adaptation, distribution and reproduction in any medium or format, as long as you give appropriate credit to the original author(s) and the source, provide a link to the Creative Commons license, and indicate if changes were made. The images or other third party material in this article are included in the article's Creative Commons license, unless indicated otherwise in a credit line to the material. If material is not included in the article's Creative Commons license and your intended use is not permitted by statutory regulation or exceeds the permitted use, you will need to obtain permission directly from the copyright holder. To view a copy of this license, visit http://creativecommons. org/licenses/by/4.0/.

(c) The Author(s) 2017 